\title{
Genetics and public health-evolution, or revolution?
}

\author{
Jane L Halliday, Veronica R Collins, Mary Anne Aitken, Martin P M Richards, Craig A Olsson
}

J Epidemiol Community Health 2004;58:894-899. doi: 10.1136/jech.2003.018515

During the 19th and early 20th century, public health and genetics shared common ground through similar approaches to health promotion in the population. By the mid-20th century there was a division between public health and genetics, with eugenicists estranged and clinical genetics focused on single gene disorders, usually only relevant to small numbers of people. Now through a common interest in the aetiology of complex diseases such as heart disease and cancer, there is a need for people working in public health and genetics to collaborate. This is not a comfortable convergence for many, particularly those in public health. Nine main concerns are reviewed: fear of eugenics; genetic reductionism; predictive power of genes; non-modifiable risk factors; rights of individuals compared with populations; resource allocation; commercial imperative; discrimination; and understanding and education. This paper aims to contribute to the thinking and discussion about an evolutionary, multidisciplinary approach to understanding, preventing, and treating complex diseases.

See end of article for authors' affiliations

Correspondence to: Associate Professor J Halliday, Public Health Genetics Unit, Murdoch Childrens Research Institute, 10th Floor, Royal Children's Hospital, Flemington Road,

Parkville, VIC 3052

Australia; jane.halliday@ mcri.edu.au

Accepted for publication 6 March 2004
Simultaneously, public health was focused on preventing disease primarily through the control of infection and malnutrition. Paradoxically, it seemed there was an unspoken collaboration in place whereby public health could continue to prevent the deaths of the unfit so long as eugenics prevented the unfit from passing on their defects, ${ }^{8}$ thus counteracting "degeneration" of the population. ${ }^{9}$

This connection is unpalatable to public health practitioners today. However, it was not until the 1940 s that many people, including those involved with public health, withdrew their support for eugenics, as the ethics behind these practices were increasingly questioned. ${ }^{10}$ By the 1950s, human genetics had disentangled itself from eugenics and the practice of non-directive genetic counselling was introduced. ${ }^{11}{ }^{12}$ The science of human genetics was focused on micro-level health influences, and clinical genetics on rare, single gene disorders, providing diagnosis, risk estimation, reproductive options, and some newborn screening. ${ }^{13}$ Meanwhile, public health was dealing with macro-level social, environmental, and behavioural health influences and, apart from newborn screening activities, there seemed little need or opportunity for dialogue between the two disciplines.

This divergence was maintained throughout the second half of the 20th century with public health shifting focus from infectious diseases to complex, chronic diseases and geneticists concentrated on mapping the human genome. ${ }^{14-16}$ Now, genetic information relevant to common, complex diseases is being discovered, ${ }^{17}$ providing opportunities for convergence of the two disciplines. Such opportunities have, however, been met with some scepticism. One reason is the over-optimistic claims made by some scientists about the potential impact of new genetic knowledge on the understanding of, and ability to intervene in, the disease process. ${ }^{12}{ }^{18}$ The hype around genetic research that has arisen from the Human Genome Project ("genohype") does nothing to dispel the scepticism of the public health community. However, effective presentation of well researched science and expression of realistic views should facilitate a more comfortable convergence in time. ${ }^{16} 19-23$

The aim of this paper is to identify and describe some of the major barriers to effective convergence and in doing so, ascribe to an evolutionary, not revolutionary, approach to prevention and management of complex diseases from a multidisciplinary perspective.

\section{(1) FEAR OF EUGENICS}

Fear exists that a subtle form of "back door" eugenics may result from use of genetic 
information at a population level. ${ }^{24}$ This fear is fed by fictitious examples of selective breeding that abound in fiction $^{25-27}$ and cinema (for example, the film "Gattaca"). Selective breeding on the basis of one's genealogy, appearance, and health are not new, ${ }^{28}{ }^{29}$ but it is the perceived power of genetic information that creates additional fear.

The demarcation between the eugenicists of yesteryear and those involved in human genetics today has been described as a rhetorical ploy, with too little attention paid to social circumstances in which people now make choices and ramifications of these for society. ${ }^{30}$ Genetic testing, especially prenatal testing, is usually promoted as being voluntary and with informed choice. However, individual choice may be constrained by the service availability, incomplete information, and professional attitudes, so as to be tantamount to a eugenic policy. ${ }^{24}$ Although not directly addressing this choice issue, there are safeguards in place, both regulatory and non-regulatory, that monitor and raise awareness of potential uses and abuses of genetic information. Examples include ethics committees, disability movements, action groups, the powerful media, and loud critical commentators.

Of course, the main objective for using genetic information in public health today is not to enhance, change, or remove one's genes, but to promote their optimal expression. The possibility of a new eugenics era cannot be ruled out, and neither can changes in social values and economic influences. Therefore concern about eugenic activities should be taken seriously and the scientific community is responsible for engaging the public in informed debate around this issue.

\section{(2) THE PREDICTIVE POWER OF GENES}

"Genetic determinism" is a belief that genes are the sole determinants of traits or diseases. ${ }^{6}$ There is a tendency to see genetic information as explaining too much without attention to the complex interrelations between genetic and environmental factors. ${ }^{31}{ }^{32}$ To many, this idea is obviously erroneous, but understandable given the way genetic discoveries are often reported in the media where deterministic views are implied or stated overtly. ${ }^{33}$ To those not familiar with the field, it is then difficult to determine the significance of the research.

The value of studies that attempt to identify associations between genetic variation and particular outcomes (genetic association studies) is currently under debate, ${ }^{34-37}$ as it is difficult to determine the extent of publication bias, ${ }^{38}$ and whether observed associations represent causal relations or are just statistical artefacts. There are ongoing efforts to improve study design, ${ }^{36} 37{ }^{40}$ and guidelines for synthesising and interpreting evidence from genetic association studies, ${ }^{41-43}$ all potentially benefiting from the input of epidemiologists.

Social and philosophical analyses of genetic determinism can be found elsewhere. ${ }^{614}$ More pertinent here is the scientific basis for the predictive power of genetic information. Contrary to beliefs of genetic determinists, most gene variants associated with complex diseases (in contrast with the rare, highly penetrant mutations that cause some cancers and conditions like Huntington disease) do not, and will not, have much predictive power on their own. ${ }^{19} 45$ However new technologies such as that associated with microarrays, which use DNA or protein "chips", can test simultaneously for a

\section{Key point}

This paper aims to provide a review of the current concerns about public health genetics and demonstrate that this evolving field can contribute substantially to the health and wellbeing of the global community. large number of genetic variants, each conferring some susceptibility to disease, or can measure presence and levels of biomarkers coded for by genes. By combining this genetic and/or biomarker information with behavioural and environmental risk factor information, predictive power will be increased. ${ }^{46}{ }^{47}$ However, not all genetic variants found to be associated with disease will be clinically useful. Genetic tests should be introduced only when the predictive power is established within particular populations, and with knowledge of the "number needed to screen" (analogous to the "number needed to treat" concept) to prevent one case of disease. ${ }^{45}$ Cost-benefit analyses and rigorous evaluation of genetic screening programmes is essential..$^{48-53}$

\section{(3) GENETIC REDUCTIONISM}

Some public health professionals are concerned that, at a time when there are moves to address inequalities in socioeconomic and political factors affecting health, ${ }^{54-56}$ identification of genetic risk might move us back towards the "single cause for single disease" paradigm (analogous to the "germ theory" of the 19-20th century). A reductionist approach can be useful for identifying genetic associations with disease and elucidating aetiological pathways ${ }^{36}$ in a research setting, but does not reflect the way genes operate in complex biological systems.

The term "individualistic fallacy" has been used to describe the situation where the major population determinants of health are ignored and the focus is on individual level variables-a criticism of genetic as well as other individual risk factor epidemiology. ${ }^{5455} 5758$ The challenge that has been presented to epidemiologists is to embrace multiple levels of risk, from the molecular to the population and societal level $^{59}{ }^{60}$ and new statistical techniques are being designed to integrate these levels of risk. ${ }^{61}{ }^{62}$

\section{(4) NON-MODIFIABLE RISK FACTORS}

Public health evolved on the premise that genes could not be modified, ${ }^{63}$ effectively disqualifying them as targets for intervention. However, for complex diseases, genetic information may be used either pre-symptomatically or after disease onset, for targeted interventions including diet, medication, and lifestyle modifications. Genetic information may motivate people to improve their health behaviour, or, at the other extreme, it may lead to a fatalistic view of genetic risk with people shunning preventive behaviours or treatments. ${ }^{64}$ As yet, evidence is lacking to support or refute either of these outcomes. The use of genetic information to improve risk identification may emphasise the high risk approach to public health. ${ }^{65}{ }^{66}$ Debates about the future of epidemiology and public health often depict "high risk" and "population" approaches to prevention as adversarial. ${ }^{54} 586768$ Alternatively, they could be considered complementary, each approach having its merits in different circumstances.

Presently there are few DNA based tests available for people at risk of complex conditions such as coronary heart disease. ${ }^{69}$ However, there is the possibility of genomically based, tailor made diets for disease prevention and management ${ }^{69-72}$ with plasma lipid response to dietary intervention modified by variants of genes such as ApoE.

\section{Policy implications}

This paper could indirectly impact on policy by providing an overview of important issues. It may be especially useful for those with a public health background who may be involved in making policy decisions about new genetic screening programmes or other human genetic services. 
Genetic information is often used to identify effective drugs in cancer patients. ${ }^{73}$ Pharmacogenetics offers further potential for tertiary prevention, through use of a person's genetic profile to prevent adverse or non-reactions to prescribed drugs, as well as determine appropriate doses or combinations of drugs. ${ }^{74}{ }^{75}$ Although personalised tailoring of medication holds promise, widespread application of pharmacogenomic profiling may be years away. ${ }^{76}$ Moreover, there are questions about economic implications, consent, privacy, "orphan diseases", racial stereotyping, ${ }^{77}$ and more. The Nuffield Council on Bioethics in the UK has produced a report that summarises the ethical issues and promotes discussion for the development of future policy and practice (http://www.nuffieldbioethics.org/pharmacogenetics). Some say that within a decade pharmacogenetic testing will be having a considerable effect on health care, ${ }^{5}$ bearing in mind the same was said of gene therapy more than two decades ago.

Genetic information can help elucidate the causal role of modifiable environmental risk factors through Mendelian randomisation. ${ }^{40}{ }^{78}$ Mendel's law of random assortment of genetic material means that study groups defined by genetic make up will not have systematic differences in confounders (both measured and unmeasured), thus mimicking a randomised trial. In genetic association studies, which utilise such groups, any association identified between a genetic variation known to affect the level of a hypothesised environmental risk factor and the disease should not be attributable to confounding, and provides support for a truly causal relation between the risk factor and disease. Although there are limitations to this approach, ${ }^{79}$ many see the potential for using genetic association studies in this way. ${ }^{78} 79$

\section{(5) INDIVIDUALS OR POPULATIONS?}

Clinical genetics has traditionally emphasised personal choice and decision making for individuals within a family context and often for rare conditions. ${ }^{80}$ Now, both genetic scientists and clinicians face ethical and social questions with ramifications for the broader population. ${ }^{630}$ Families with rare genetic conditions will always need specialised services but geneticists will also be increasingly involved in community based genetic screening programmes.

On the other hand, public health, which seeks to improve the health of populations, has had to recognise the importance of the individual. Since the institution of the Nuremberg Code in 1949 and the need for voluntary consent in research, along with more general societal changes in the developed world (for example, Universal Declaration of Human Rights in 1948), there has been a move towards the prominence of individual rights and freedoms. One consequence is that issues of privacy can take precedence over the public good. In the USA, primacy is given to personal autonomy in handling of risk information, ahead of promoting societal change that may face powerful opposing interests. ${ }^{58}$ Privacy issues extend to use of medical record information ${ }^{81}$ now protected by the enactment of new laws. ${ }^{82}$ These changes offer challenges to public health practitioners and epidemiologists to encompass the individual view while maintaining efforts to promote the health of populations through a collective approach. This may be facilitated via informed consent and also the provision to opt out of public health programmes, such as that now in place for newborn screening. ${ }^{83}$

\section{(6) RESOURCE ALLOCATION}

Commentators have highlighted feelings about the imbalance in distribution of public resources in health care. ${ }^{84} \mathrm{~A}$ major area of concern is the prioritisation of competitive research funding in favour of genetics. Figures are not readily available to determine the extent of this problem, but one example of large investment in genetic research is "Biobank" in the UK. Forty five million pounds have been allocated by the Medical Research Council, the Wellcome Trust, and the Department of Health to gather genetic and epidemiological data on 500000 people to explore the role of genes, environment, and lifestyle in health. Despite the large investment, Wellcome have stated that "it (Biobank) won't affect funding for other projects at Wellcome". ${ }^{85}$ Differing opinions exist as to its validity, peer review process, ${ }^{86}$ tendering, costs, ethics, and data security. ${ }^{85}$ Some concerns may be allayed by the "Ethics and Governance Framework", a discussion document to be reviewed by the Board of Directors of Biobank (see http://www.biobank.ac.uk).

Another area of concern is the predicted investment in health services required for new genetic technologies and tests. State health departments in the US have recognised the need to realign their activities to meet future developments in genetics $^{87}$ with funding stated as the greatest concern. The UK has produced the white paper where priorities are given to the application of genetics within the National Health Service. ${ }^{88}$ Genetics laboratories, improving awareness of the usefulness of genetics for families with inherited cancers and heart disease, pharmacogenetic developments, and gene therapy have all been targeted for funding. The recognition of the need to have a strategic financial plan for genetic services is considered by some as a "milestone in the development of national policy" in the UK. ${ }^{89}$

Issues of resource allocation are undoubtedly more serious in developing countries because of scientific and technical problems related to introducing genetic technologies in countries with limited resources, as well as substantial social and environmental problems. ${ }^{90}{ }^{91}$ Efforts are being made to reduce the "genomics divide" that is growing between countries who are using genetic knowledge and those who cannot. ${ }^{92}$ A symposium on community genetics in developing countries was held in India in 2002.93 An estimated half million babies are born each year in India with a birth defect, and birth defects have overtaken infection as a cause of perinatal mortality. Therefore, government support of existing, integrated local and district health centres and practitioners has been strongly advocated. The symposium discussed the establishment of community controlled prenatal and newborn screening programmes, ${ }^{94}$ hand in hand with education and awareness campaigns.

Other major health problems in developing countries may benefit from advances in genetics. If the newly described gene sequences of mosquitoes could be genetically changed to block the cycle of the parasite transmission, the incidence of malaria infection could be reduced..$^{95}$ There is also possibility of developing DNA based vaccines for AIDS, and an oral vaccine for hepatitis B. To seriously impact on health in developing countries through genomics, a global approach with "innovative financing mechanisms" is required..$^{92}$

\section{(7) COMMERCIAL IMPERATIVE}

Commercial opportunities exist for pharmaceutical and biotechnology industries in response to growing market pressure on development and use of genetic tests, medicines, and information. ${ }^{96}$ Commercial laboratories may bypass recommended pre-test genetic counselling ${ }^{97}$ when offering "over the counter" genetic testing. ${ }^{98}$ The Human Genetics Commission (HGC) in the UK (http://www.hgc.gov.uk/ genesdirect/) does not discount this method of provision of genetic information in some situations if correct measures are in place to prevent misuse of genetic information, and there is adequate funding within the NHS to permit equal access. ${ }^{99}$ They provide recommendations for marketing high quality 
tests and a framework for regulation of strict professional standards.

There are over 100 web sites worldwide offering genetic testing for a variety of purposes, for example, parentage, identity, forensic, immigration, health related genetic tests, and DNA banking. ${ }^{100}$ Significantly, 12 commercial organisations have been identified that offer adult genetic susceptibility testing. ${ }^{101}$ Any promotion of this type of testing will have ramifications for the public purse because of the increased need for follow up health services. It may also exacerbate inequalities in access and there are concerns about privacy, safety, and quality. The above HGC report recommends the establishment of a web site, developed through international collaboration, that acts as a "trusted source" of information, effectively setting up appropriate controls. Whether this is a realistic option, or whether strong legislative measures are required, remains to be seen.

Patents for gene sequences that provide genetic diagnostic or risk information have been granted. Some patents, such as that related to the kit diagnosing cystic fibrosis, are well accepted and widely used with royalties being paid. However, considerable concern has been raised about others, ${ }^{102}$ because of the way rights to the patents are exercised and enforced, and the associated costs. It is unclear how often patents for gene sequences related to susceptibility genes for complex conditions will be granted and then enforced, but they potentially have much greater public health implications. This topic is beyond the scope of this paper, but is high on the agenda of many lawyers, ${ }^{102}{ }^{103}$ geneticists, and other concerned individuals ${ }^{104}$ and groups (for example, http:// www.nuffieldbioethics.org).

\section{(8) DISCRIMINATION}

Genetically susceptible population subgroups may be identified, marginalised, or discriminated against in various ways - the creation of a "genetic underclass". ${ }^{105}{ }^{106}$ Family relationships, insurance (life, travel, and health), employment, finance, adoption, migration, forensic, and legal settings (paternity testing) are all examples of where genetic discrimination may occur. There is also concern that pharmacogenetics could lead to a form of population genetic discrimination whereby drug companies concentrate on producing drugs for those who carry gene variants common in western industrialised societies. Those elsewhere with rarer or "orphan" alleles may be ignored. In reality there have not been widespread cases of genetic discrimination yet, ${ }^{105}$ but possibilities do exist. ${ }^{107}$

In the UK there is a voluntary agreement that only genetic tests thought to be sufficiently predictive by the Genetics and Insurance Committee of the Department of Health, will be used for life and critical illness insurance. Currently, this applies to Huntington disease, with familial breast/ovarian cancer and familial Alzheimer disease under consideration. The UK HGC has considered the issue of discrimination through misuse of genetic information in non-clinical settings. They state that there must be ample opportunity for discussion on the use of genetic information and related issues (such as use of family history information) before the existing moratorium is lifted. ${ }^{108} 109$

The Australian Law Reform Commission discussion paper on protection of human genetic information ${ }^{82}$ makes recommendations for changes to the anti-discrimination laws and development of disability discrimination standards that deal with the collection and use of genetic information, particularly by employers. This is different from the UK where legislation separate from the disability laws is recommended. In the US, health insurance and employment have been the focus of most attention. After many years of negotiation, the Genetic Information Nondiscrimination Act of 2003 was passed by the US Senate and it now remains to be seen if it will be passed by the House of Representatives. "This bill would prevent health insurers and employers from using genetic information to determine eligibility, set premiums, or hire and fire people" (http://www.genome.gov/11510227).

\section{(9) UNDERSTANDING AND EDUCATION}

The complexity of genetics dictates the need for specialised languages and bodies of information. ${ }^{110}$ Genetic literacy assumes that the average person can evaluate the credibility of information that has implications for personal and public health, ${ }^{111}$ but most do not have this skill. The "lay understanding of genetics" has been explored by social scientists, ${ }^{112}{ }^{113}$ showing the need for attention to be paid to this area across all age groups. Public education campaigns and responsible journalism will contribute to better understanding and provide perspective to the messages about advances in genetics. ${ }^{50}$

Multi-disciplinary education programmes for health professionals are needed on the scientific, ethical, legal, and social issues related to public health genetics, as are programmes on bioinformatics and statistical genetics, cultural anthropology and health behaviour. ${ }^{114}$ Graduate courses have been established in the USA, ${ }^{114}$ and in the UK organisations such as the Cambridge Public Health and Genetics Unit (PHGU) have been involved in providing courses. A report released by the PHGU has made recommendations for how genetics education of all NHS health professionals might be advanced (http://www.phgu.org.uk/ about_phgu/education.html).

\section{CONVERGENCE OF THE TWO DISCIPLINES}

The evolution of public health genetics has already begun as shown by the plethora of peer reviewed papers from both the public health and genetics communities, as well as many public consultation documents. The literature consists not only of basic research, but many authors are grappling with issues ranging from the methodological to the health applications of genetic research. The broad range of views expressed and topics covered are indicative of the energy and life of this new field. Khoury ${ }^{115}$ describes a continuum from "genetic disease" to "genetic information" in health and we are presently partway along the path. A greater use of family history information to stratify individuals into average, moderate, and high risk for common diseases has been proposed, to guide prevention strategies. Already those identified as high risk based on family history are benefiting from predictive testing for single gene disorders (for example, some cancers), with those at moderate risk next in line. In time, testing might be broadened to those at average risk of common complex disorders.

In outlining these nine issues critical to genetics and public health and reporting current initiatives and relevant research addressing these concerns, the need for an evolutionary, adaptive approach becomes apparent. There cannot be a revolution, it being essential that there is continued debate, public engagement, common sense, and academic development, all underpinned by ethical analysis, some legislative regulation, and policy development. This takes time, but will clarify uncertainties, and most importantly affirm that research and development in genetics need not diminish the importance of social and environmental determinants of health, and can in fact render the interventions more effective than before.

\section{ACKNOWLEDGEMENTS}

We wish to thank the Behavioural Theme Grant team at the Murdoch Childrens Research Institute. Jane Halliday is supported by a grant from the National Health and Medical Research Council. 


\section{Authors' affiliations}

J L Halliday, V R Collins, M A Aitken, C A Olsson, Murdoch Childrens Research Institute, Royal Children's Hospital, Parkville, Australia J L Halliday, V R Collins, M A Aitken, Department of Paediatrics, University of Melbourne, Melbourne, Australia M P M Richards, Centre for Family Research, University of Cambridge, UK

J L Halliday and V R Collins contributed equally to this work.

Conflicts of interest: none declared.

\section{REFERENCES}

1 Collins FS, McKusick VA. Implications of the Human Genome Project for medical science. JAMA 2001;285:540-4.

2 Bell J. The new genetics in clinical practice. BMJ 1998;316:618-20

3 van Ommen GJB, Bakker E, den Dunnen JT. The human genome project and the future of diagnostics, treatment and prevention. Lancet 1999;354(suppl 1).5-19.

4 Radda G, Dexter TM, Meade T. The need for independent scientific peer review of Biobank UK. Reply from Biobank UK. Lancet 2002;359:2282

5 Abbott A. With your genes? Take one of these, three times a day. Nature 2003:425:760-2.

6 Buchanan A, Brock DW, Daniels N, et al. From chance to choice: genetics and justice. Cambridge: Cambridge University Press, 2000.

7 Crew FAE, Darlington CD, Haldane JBS, et al. Social biology and population improvement. Nature 1939:144:521-2.

8 Pernick MS. Eugenics and public health in American history. Am J Public Health 1997;87:1767-72.

9 Darwin C. The descent of man. London: John Murray, 1871.

10 Paul DB, Spencer HG. The hidden science of eugenics. Nature 1995;374:302-4.

11 Resta RG. The historical perspective: Sheldon Reed and 50 years of genetic counseling. J Genet Counsel 1997:6:375-7.

12 Reed SC. Counseling in human genetics. Dight Institute Bulletin 1947:6:7-21.

13 Pass K. Lessons learned from newborn screening for Phenylketonuria. In: Khoury M, Burke W, Thompson E, eds. Genetics and public health in the 21 st century. Oxford: Oxford University Press, 2000:385-404.

14 McPherson JD, Marra M, Hillier A, et al. A physical map of the human genome. Nature $2001 ; 409: 934-41$

15 Venter JC, Adams MD, Myers EW, et al. The sequence of the human genome. Science 2001;291:1304-51.

16 Yoon PW, Chen B, Faucett A, et al. Public health impact of genetic tests at the end of the 20th century. Genet Med 2001;3:405-10.

17 Mathew C. Postgenomic technologies: hunting the genes for common disorders. BMJ 2001;322:1031-4.

18 Duff G. Genomic medicine as preventive medicine. BMJ 2001:322:1016.

19 Holtzman NA, Marteau TM. Will genetics revolutionize medicine? N Engl J Med 2000;343:141-4

20 Whiteman D, Hayward N. Impact of the Human Genome Project on medical genetics. Today's Life Science 2001;Jul/Aug:38-42.

21 Holtzman N. Three views of genetics: the enthusiast, the visionary and the sceptic: the cautious view. BMJ 2001;322:1017.

22 Weiss KM, Terwilliger JD. How many diseases does it take to map a gene with SNPs? Nat Genet 2000:26:151-7.

23 Harrap S, Petrou S. Utility of genetic approaches to common cardiovascula diseases. Am J Physiol Heart Circ Physiol 2001;281:H1-6.

24 Duster T. Backdoor to eugenics. New York: Routledge, 1990.

25 Little P. Genetic destinies. Oxford: Oxford University Press, 2002.

26 Atwood M. Oryx and Crake. New York: Random House, 2003.

27 Follett K. The third twin. London: MacMillan, 1996.

28 Richardson A. Love and eugenics in the late nineteenth century. Oxford: Oxford University Press, 2003

29 Richards MPM. Perfecting people: selective breeding at the Oneida Community 1869-1879 and the eugenic movement. New Genetics and Society 2004;23:47-71.

30 Kerr A, Shakespeare T. Genetics politics: from eugenics to genome. Cheltenham: New Clarion Press, 2002.

31 Richards M. How distinctive is genetic information? Stud Hist Phil Biol Biomed Sci 2001;32:663-87.

32 Dennett DC. Darwin's dangerous idea. New York: Simon and Shuster, 1995.

33 Petersen A. Biofantasies: genetics and medicine in the print news media. Soc Sci Med 2001;52:1255-68.

34 Risch NJ. Searching for genetic determinants in the new millenium. Nature 2000:405:847-56

35 Gambaro G, Anglani F, D'Angelo A. Association studies of genetic polymorphisms and complex disease. Lancet 2000;355:308-11.

36 Colhoun HM, McKeigue PM, Davey Smith G. Problems of reporting genetic associations with complex outcomes. Lancet 2003;361:865-72.

37 Cardon LR, Palmer L. Population stratification and spurious allelic association. Lancet 2003;361:598-604.

38 Editor. In search of genetic precision. Lancet 2003;361:357.

39 Lohmueller KE, Pearce CL, Pike M, et al. Meta-analysis of genetic association studies supports a contribution of common variants to susceptibility to common disease. Nat Genet 2003:33:177-82.

40 Clayton D, McKeigue PM. Epidemiological methods for studying genes and environmental factors in complex diseases. Lancet 2001;358:1356-60.
41 Page GP, George V, Go RC, et al. "Are we there yet? ": deciding when one has demonstrated specific genetic causation in complex diseases and quantitative traits, Am J Hum Genet 2003;73:71 1-19.

42 Little J, Bradley L, Bray MS, et al. Reporting, appraising, and integrating data on genotype prevalence and gene-disease associations. Am J Epidemiol 2002;156:300-10

43 Little J, Khoury MJ, Bradley L, et al. The human genome project is complete. How do we develop a handle for the pump? Am J Epidemiol 2003:157:667-73

44 Nelkin D, Lindee S. The DNA mystique: the gene as a cultural icon. New York: W H Freeman, 1995.

45 Vineis $\mathrm{P}$, Schulte $\mathrm{P}, \mathrm{McM}$ Michael AJ. Misconceptions about the use of genetic tests in populations. Lancet 2001;357:709-12.

46 Khoury M, Wagener D. Epidemiological evaluation of the use of genetics to improve the predictive value of disease risk factors. Am J Hum Genet 1995;56:835-44.

47 Yang Q, Khoury MJ, Botto L, et al. Improving the prediction of complex diseases by testing for multiple disease-susceptibility genes. Am J Hum Genet 2003:72:636-49.

48 Melzer D, Zimmern R. Genetics and medicalisation. BMJ 2002;324:863-4.

49 Burke W, Pinsky LE, Press NA. Categorizing genetic tests to identify their ethical, legal, and social implications. Am J Med Genet 2001;106:233-40.

50 Khoury MJ, Thrasher JF, Burke W, et al. Challenges in communicating genetics: a public health approach. Genet Med 2000;2:198-202.

51 Burke W, Atkins D, Gwinn M, et al. Genetic test evaluation; information needs of clinicians, policy makers, and the public. Am J Epidemiol 2002:156:311-18.

52 Hall J, Viney R, Haas M. Taking a count: the evaluation of genetic testing. Aust N Z J Public Health 1998;22:754-8.

53 Holtzman NA, Watson MS. Promoting safe and effective genetic testing in the United States. Final report of the Task Force on Genetic Testing. Baltimore: Johns Hopkins University Press, 1998.

54 Pearce N. The ecological fallacy strikes back. J Epidemiol Community Health 2000:54:326-7.

55 McMichael AJ. Prisoners of the proximate; loosening the constraints on epidemiology in an age of change. Am J Epidemiol 1999;149:887-97.

56 Turrell G, Oldenburg B, McGuffog I, et al. Socioeconomic determinants of health: towards a national research program and a policy and intervention agenda. Canberra: Queensland University of Technology, School of Public Health, Ausinfo, 1999

57 Diez-Roux A. On genes, individuals, society and epidemiology Am J Epidemiol 1998; 148:1027-32.

58 Rockhill B. The privatization of risk. Am J Public Health 2001:91:365-8.

59 McKinlay JB, Marceau LD. A tale of 3 tails. Am J Public Health 1999;89:295-8

60 Susser M, Susser E. Choosing a future for epidemiology: II. From black box to Chinese boxes and eco-epidemiology. Am J Public Health 1996;86:674-7

61 Goldstein H. Multilevel statistical models. London: Arnold, 1995.

62 Subramanian SV, Kawachi I, Kennedy BP. Does the state you live in make a difference? Multilevel analysis of self-rated health in the US. Soc Sci Med 2001;53:9-19.

63 Kerr C. Genetic testing and public health. Aust N Z J Public Health 1996;20:451-2

64 Hunt K, Davison C, Emslie C, et al. Are perceptions of a family history of heart disease related to health-related attitudes and behaviour. Health Educ Res 2000;15:131-43.

65 Rose G. Sick individuals and sick populations. Int J Epidemiol 1985;30:427-32.

66 Schork NJ, Fallin D, Lanchbury S. Single nucleotide polymorphisms and the future of genetic epidemiology. Clin Genet 2000;58:250-64.

67 Begg CB. The search for cancer risk factors: When can we stop looking? Am J Public Health 2001;91:360-4

68 Colditz GA. Cancer culture: epidemics, human behaviour, and the dubious search for new risk factors. Am J Public Health 2001:91:357-9.

69 Scheuner MT. Genetic evaluation for coronary artery disease. Genet Med 2003:5:269-85.

70 Stover PJ, Garza C. Bringing individuality to public health recommendations. J Nutr 2002:132:2476-80S.

71 Ordovas JM. Gene-diet interaction and plasma lipid response to dietary intervention. Curr Atheroscler Rep 2001;3:200-8.

72 Erkkila AT, Sarkkinen ES, Lindi V, et al. APOE polymorphism and the hypertriglyceridemic effect of dietary sucrose. Am J Clin Nutr 2001;73:669-70.

73 Innocenti F, Ratain MJ. Update on pharmacogenetics in cancer chemotherapy. Eur J Cancer 2002;38:639-44.

74 Omenn G. Prospects for pharmacogenetics and ecogenetics in the new millenium. Drug Metab Dispos 2001;29:611-14.

75 Basile VS, Masellis M, Potkin SG, et al. Pharmacogenomics in schizophrenia: the quest for individualized therapy. Hum Mol Genet 2002;11:2517-30

76 Goldstein DB. Pharmacogenetics in the laboratory and the clinic. NEngl JMed 2003:348:553-6.

77 Furr LA. Perceptions of genetics research as harmful to society: differences among samples of African-Americans and European-Americans. Gen Testing 2002;6:25-30

78 Davey Smith G, Ebrahim S. 'Mendelian randomization': can genetic epidemiology contribute to understanding environmental determinants of disease? Int J Epidemiol 2003:32:1-22.

79 Little J, Khoury MJ. Mendelian randomisation: a new spin or real progress? Lancet 2003:362:930-1. 
80 Harper P. Practical genetic counselling. 5th edn. Oxford: ButterworthHeinemann, 1998.

81 Bruinsma F, Venn A, Skene L. Legal and ethical issues in record linkage studies. Aust Epidemiol 1999;6:15-17.

82 ALRC and NHMRC. Protection of human genetic information (discussion paper). Sydney: Australian Law Reform Commission and National Health and Medical Research Council, discussion paper 66, 2002.

83 Hiller EH, Landenburger G, Natowicz MR. Public participation in medical policy-making and the status of consumer autonomy: the example of newborn-screening programs in the United States. Am J Public Health 1997;87:1280-8.

84 Leeder S. Resource allocation and the genetic revolution. (http:// www.onlineopinion.com.ao/view.asp?article $=1162$ ).

85 Barbour V. UK Biobank: a project in search of a protocol? Lancet 2003;361:1734-8.

86 Wallace $\mathrm{H}$. The need for independent scientific peer review of Biobank UK [Author reply]. Lancet 2002;359:2282.

87 Piper MA, Lindenmayer JM, Lengerich EJ, et al. The role of public health agencies in genetics and disease prevention: results of a national survey. Public Health Rep 2001;116:22-31.

88 Department of Health. Our inheritance, our future: realising the potential of genetics in the NHS. London: Department of Health, 2003.

89 Stewart A, Zimmern R. (Almost) three cheers for UK genetics white paper. Lancet 2003;362:341-2.

90 Pang T. The impact of genomics on global health. Am J Public Health 2002;92:1077-9.

91 Bloom BR, Trach DD. Genetics and developing countries. BMJ 2001;322: 1006-7.

92 Singer PA, Daar AS. Harnessing genomics and biotechnology to improve global health equity. Science 2001;294:87-9.

93 Bittles AH, Savithri HS, Rao NA. Community genetics in developing countries. Community Genet 2002;5:151-2.

94 Verma IC, Bijarmia S. The burden of genetic disorders in India and a framework for community control. Community Genet 2002;5:192-6.

95 Thorsteinsdottir H, Daar AS, Smith RD, et al. Genomics-a global public good? Lancet 2003;361:891-2.

96 Caulfield T. Genetics services and market forces. Nat Rev Genet 2002;3:734

97 NHMRC Genetics Working Party. Ethical aspects of human genetic testing an information paper. Canberra: Commonwealth of Australia, 2000.
98 Tizzard J. Debating genetic susceptibility tests. 4/11/02-11/11/02 ed: BIONEWS-Progress Educational Trust, (http://www.progress.org.uk/ News/, 2002).

99 Human Genetics Commission. Genes direct: ensuring the effective oversight of genetic tests supplied directly to the public. London: UK Department of Health, 2003.

100 Gollust SE, Hull SC, Wilfond BS. Bringing you the world of genetics: direct to consumer genetic services on the internet. [Abstract]. Am J Hum Genet 2002;71:171.

101 Williams-Jones B. Where there's a web, there's a way: commercial genetic testing and the internet. Community Genet 2003;6:46-57.

102 Andrews LB. Genes and patent policy: rethinking intellectual property rights. Nat Rev Genet 2002;3:803-8.

103 Caulfield TA, Knoppers BM, Gold ER, et al. Genetic technologies, health care policy and the patent bargain. Clin Genet 2003;63:15-18.

104 Sulston J. Beyond release: the equitable use of genomic information. Lancet 2003;362:400-2.

105 Rothenberg KH, Terry SF. Before it's too late-addressing fear of genetic information. Science 2002;297:196-7.

106 Keays D. The legal implications of genetic testing: insurance, employment and privacy. J Law Med 1999;6:357-72.

107 Otlowski MF, Taylor SD, Barlow-Stewart KK. Australian empirical study into genetic discrimination. Genet Med 2002:4:392-5.

108 Human Genetics Commission. Inside information: balancing interests in the use of personal genetic data. London: Department of Health, 2002.

109 Warren V. Genetics and insurance: a possible solution. [Letter]. BMJ 2001;322:1060.

110 Potter JD. At the interfaces of epidemiology, genetics and genomics. Nat Rev Genet 2001;2:142-7.

111 Mclnerney JD. Education in a genomic world. J Med Philos 2002;27:369-90.

112 Richards M, Ponder M. Lay understanding of genetics: a test of a hypothesis. J Med Genet 1996;33:1032-6.

113 Kerr A, Cunningham-Burley S, Amos A. The new genetics and health: mobilizing lay expertise. Public Understanding of Science 1998;7:41-60.

114 Austin MA, Peyser PA, Khoury MJ. The interface of genetics and public health: research and educational challenges. Annu Rev Public Health 2000;21:81-99

115 Khoury MJ. Genetics and genomics in practice: the continuum from genetic disease to genetic information in health and disease. Genet Med 2003;5:261-8. 